\title{
PROFITABILITY OF USAGE OF AUTOMATIC MILKING SYSTEMS
}

\author{
Juris Priekulis, Armins Laurs, Maris Rozentals, Kristaps Cinglers \\ Latvia University of Life Sciences and Technologies, Latvia \\ juris.priekulis@1lu.lv, armins.laurs@promedia.lv, maris009@inbox.lv, kcinglers@gmail.com
}

\begin{abstract}
At present there are 75 robotised milking systems or AMS operating in Latvia, and their number is increasing rapidly. Therefore, it is essential to determine the main factors that influence the economic profitability of introducing the AMS. As the research performed in the Western Europe shows, in this case the milk yield and the amount of milk milked by one AMS per year play an important role. Nevertheless, in our previous research, performed from 2008 to 2010, it was stated that also the wages of animal breeders are important. Therefore, the present article gives a comparison of the AMS and stand type parlour milking equipment considering the present economic situation kin Latvia. In the research it has been stated that for introduction of AMS approximately two times larger capital investments are necessary compared to the stand type parlour equipment that is used for serving the herd of the same size. But the AMS offer a possibility to reduce approximately two times the consumption of work of the people involved in milking. Therefore, in evaluation of the economic profitability of the AMS the wages for the animal breeders play an important role. Our research shows that introduction of AMS becomes economically profitable, compared to the stand type parlour equipment, if the wages for the workers exceed 4.5-5.0 EUR per one working hour.
\end{abstract}

Keywords: AMS, cows, costs, economic.

\section{Introduction}

The first robotised cow milking systems or AMS (automated milking systems) were introduced in Latvia in 2007, but at present there are already 75 such type milking systems operating in the country. Besides, their total number has increased rapidly during the recent years. It is due to several advantages of the AMS, but mainly due to the fact that the consumption of work of animal breeders decreases essentially as milking of cows is done without direct participation of people. In the research [1-8] it has been stated that in case of using the AMS the animals were milked in average 2.6-2.8 times per day; such cow breeding conditions correspond to animal welfare conditions much better. Therefore, introducing the AMS, the milk yields increase by 5-10\% [1-3]. Besides, also the quality of the obtained milk is higher [3; 4], as during milking the obtained milk is immediately tested according to several indicators and the milk that is not qualitative is separated.

Still, for purchasing and introduction of AMS 2-2.5 times larger capital investments are necessary than for the stand type parlour equipment that is equal compared according to the working capacity. Therefore, investigations are performed to find the most important criteria that determine the economic profitability of introduction of AMS. In the first investigations, performed in the Western Europe [2], it was found that such kind of equipment is cost effective, if the milk yield is not less than 7000-8000 kg per year. Whereas at present, the amount of milk obtained in one AMS [4] that should be not less than 500-600 tons of milk per year is considered to be the most important criterion. It should also be noted that specific operating costs are of key importance [6]. In turn, in the research [9] performed at the Latvia University of Life Sciences and Technologies from 2008 to 2010 it was stated that another important criterion is the rate of animal breeder wages. Application of the AMS becomes more profitable compared to the stand type parlour equipment, if the wages for the milkers are not less than 1000-1100 EUR per month.

However, in recent years the situation in Latvian milk farming has considerably changed. The average milk yields of cows have essentially increased in many farms already exceeding $10000 \mathrm{~kg}$ per cow per year. Besides, the wages for the animal breeders have increased reaching 900-1000 EUR per month, and the milking equipment purchasing prices have decreased. Therefore, the aim of the present article is to determine the profitability of usage of the AMS, considering the present situation.

\section{Materials and methods}

Three farms, where there are 100-200 milk cows, were selected for the research. In one of them two AMS produced by the company DeLaval are used, but in the other farms - side by side (parallel parlour) and herringbone parlour type milking stands are used (Table 1).

Table 1 
Farms selected for the research

\begin{tabular}{|c|c|c|c|}
\hline Farm No. & Farm1 & Farm 2 & Farm 3 \\
\hline Number of cows & 130 & 239 & 150 \\
\hline Milking equipment & AMS, 2 pcs. & Parallel parlour, 2x10 & Herringbone, 2x12 \\
\hline Cow mechanical mover & Not used & Cow Mover M & Cow Mover M \\
\hline $\begin{array}{c}\text { Average milk yield, } \\
\mathrm{kg}^{*} \text { year }\end{array}$ & 9480 & 11200 & 9528 \\
\hline $\begin{array}{c}\text { Milkers' load, } \\
\text { man-hours. day }\end{array}$ & 0 & 8 & 8 \\
\hline $\begin{array}{c}\text { Animal breeders' load, } \\
\text { man-hours. day }{ }^{-1} *\end{array}$ & 6 & 10 & 8 \\
\hline
\end{tabular}

*participating in the process of milking

In order to compare different technological solutions of milking cows, the whole equipment set necessary for milking and primary processing of the obtained milk was included in the calculations. Therefore, not only the exploitation costs of the milking equipment, but also the exploitation costs of the cow mechanical mover (if it is used) as well as of the milk cooler were considered. The economic profitability of the milking equipment was evaluated according to the specific machine costs and specific exploitation costs that are calculated per one cow per year. For calculation of these costs the below mentioned formulas were used.

For specific machine costs and exploitation means, EUR/cow per year

$$
I M_{\bar{i} p}=I_{r}+I_{k}+I_{r e}+I_{e l . v a k}+I_{e l . d z}+I_{\bar{u}}+I_{\bar{u} . s}+I_{d e}+I_{m a z},
$$

where $I_{r}$ - machinery specific renovation costs, EUR $\cdot \operatorname{cow}^{-1} \cdot$ year $^{-1}$;

$I_{k}$-specific external capital costs, EUR $\cdot \operatorname{cow}^{-1} \cdot$ year $^{-1}$;

$I_{r e}$ - machinery specific repair costs, EUR $\cdot \operatorname{cow}^{-1} \cdot$ year $^{-1}$;

$I_{\text {el.vak }}-$ electric energy costs consumed by the vacuum pump, EUR $\cdot \operatorname{cow}^{-1} \cdot$ year $^{-1}$;

$I_{e l . d z}$ - electric energy costs consumed for cooling milk, EUR $\cdot \operatorname{cow}^{-1} \cdot \mathrm{year}^{-1}$;

$I_{\bar{u}}-$ cold water costs consumed during the process of milking, EUR $\cdot \operatorname{cow}^{-1} \cdot$ year $^{-1}$;

$I_{\bar{u} . s}-$ electric energy costs consumed for heating water, EUR $\cdot \operatorname{cow}^{-1} \cdot$ year $^{-1}$;

$I_{d e}$ - costs of disinfectants for cow teats, EUR $\cdot \operatorname{cow}^{-1} \cdot$ year $^{-1}$;

$I_{m a z}-$ milking equipment and milk cooler washing detergent costs, EUR $\cdot \operatorname{cow}^{-1} \cdot$ year $^{-1}$.

For calculation of separate indicators included in the formula (1) the mathematical equations given in literature [10] were used.

For specific exploitation costs, EUR $\operatorname{cow}^{-1} \cdot$ year $^{-1}$

$$
I E_{\text {kop. } \bar{p} p}=I_{s . \bar{p} p}+I M_{\bar{i} p}+I_{b . \bar{p} p},
$$

where $I_{s . \bar{p}}$ - specific costs for workers' wages, EUR $\cdot \operatorname{cow}^{-1} \cdot$ year $^{-1}$;

$I_{\text {b.ip }}$ - specific exploitation costs for farm premises used for milking cows,

EUR $\cdot \operatorname{cow}^{-1} \cdot$ year $^{-1}$.

For specific costs for workers' wages, EUR $\cdot \operatorname{cow}^{-1} \cdot$ year $^{-1}$

$$
I_{\text {d.a }}=\frac{1.24 \cdot 365}{z_{g}} \cdot\left(D_{\text {sl.dienn }} \cdot i_{s l}+D_{\text {piedz.dienn. }} \cdot i_{\text {piedz }}\right),
$$

where 1.24 - coefficient considering the part of social tax paid by the employer;

$i_{s l} i_{\text {piedz }}$ - rate of wages for milkers and cow drivers, EUR·man-hour ${ }^{-1}$;

$D_{\text {sl.dienn }}-$ milkers' labour intensity, man-hour. day $^{-1}$;

$D_{\text {piedz.dienn }}$ - movers' labour intensity, man-hour $\cdot$ day $^{-1}$;

$Z_{g}$ - number of cows in the barn.

For specific exploitation costs for farm premises used for milking cows 


$$
I_{b . \bar{p} p}=k_{b \bar{u} . r e} \cdot \frac{F_{b \bar{u}} \cdot C_{b \bar{u} . \bar{p} p}}{N_{b \bar{u}} \cdot z_{g}},
$$

where $k_{b u \bar{r} r e}$ - coefficient considering the building repair costs;

$F_{b \bar{u}}$ - area of the part of premises used for milking cows, $\mathrm{m}^{2}$;

$C_{b u \overline{. i p}}$ - specific building costs of the farm premises used for milking cows; EUR $\cdot \mathrm{m}^{-2}$;

$N_{b \bar{u}}$ - normative lifetime of the buildings, usually $N_{b \bar{u}}=20$ years.

For the calculations the data on the farms given in Table 1 were used. Nevertheless, considering that in every farm the size of the cow herd is different, correction of these data was done. For this purpose it was assumed that there are 130 milk cows in all farms, i.e. the same as in farm 1 . Corresponding to this number of cows the time for milking and also labour intensity were corrected. In the calculations it was also assumed that the prices for water, disinfectants and washing detergents used in the farms are equal. Besides, the wages for the workers (milkers, cow movers) are also equal, and it can be $3.00 ; 4.00 ; 5.00 ; 6.00$ or 7.00 EUR per hour. The average milk yields can be on two different levels: 7000 and $10000 \mathrm{~kg}$ per cow per year.

\section{Results and discussion}

Information about the specific machine costs and means of exploitation costs using different kinds of milking equipment is summarized in Figure 1.

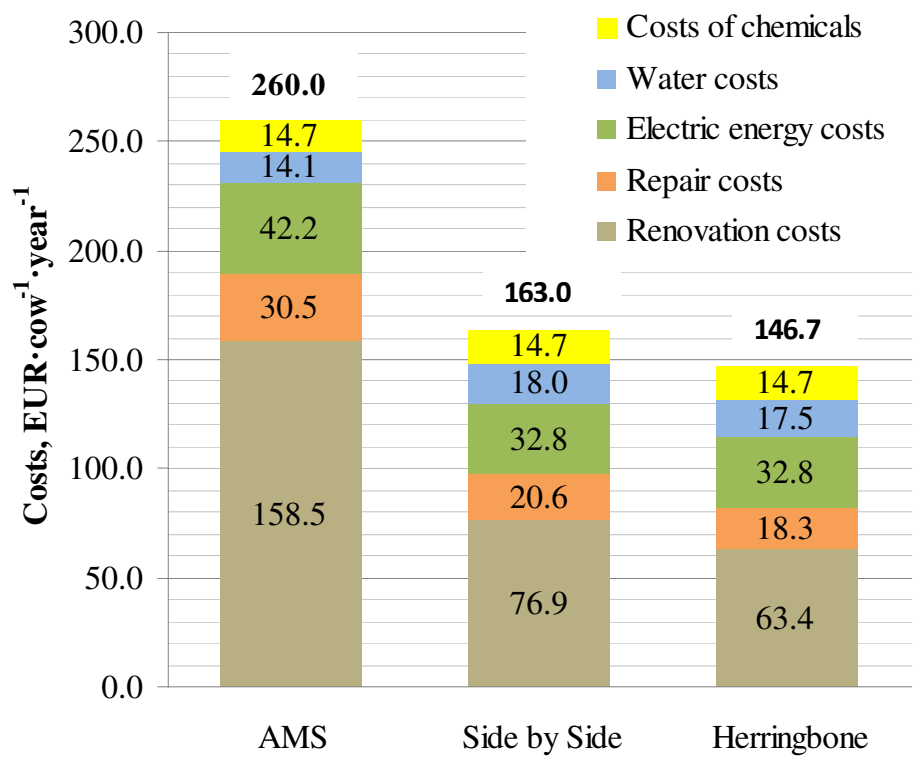

Fig. 1. Specific machine costs and means of exploitation costs for differently assembled milking technological lines, if average milk yield is $10000 \mathrm{~kg}$ per cow per year

The figure shows that the highest specific machine costs are in the first farm, where for milking cows two AMS are used. If, in turn, for this purpose the side by side parlour equipment is used, the costs are reduced by $37 \%$. But if the stand type parlour equipment with herringbone parlour arrangement is used, the costs reduce by $44 \%$. It is related to the increased capital investments for purchasing and introduction of AMS that are approximately two times higher compared to the other types of milking equipment. Besides, also the repair and technical maintenance costs for the AMS are higher (by approximately $50 \%$ ), as for repairing them assistance of qualified specialists is necessary. Also the electric energy costs are increased (by $30 \%$ ), as the cows enter the AMS also during the night time.

The proportion of the calculated specific costs for every technology is shown in Figure 2. The figure shows that in case of using the AMS, the machine costs (including also the costs of exploitation means) comprise $70.6 \%$ of the total costs, but $26.9 \%$ of the total costs are used for the wage of the worker, who several times per day stimulates the "lazy" cows to go for milking, as well as takes care 
of the AMS zone and carries out everyday technical maintenance of the AMS. In turn, the building costs or exploitation costs of the part of the premises of AMS location are $2.5 \%$ of the total costs. They are comparatively small, as the area occupied by the milking zone is only $84 \mathrm{~m}^{2}$.

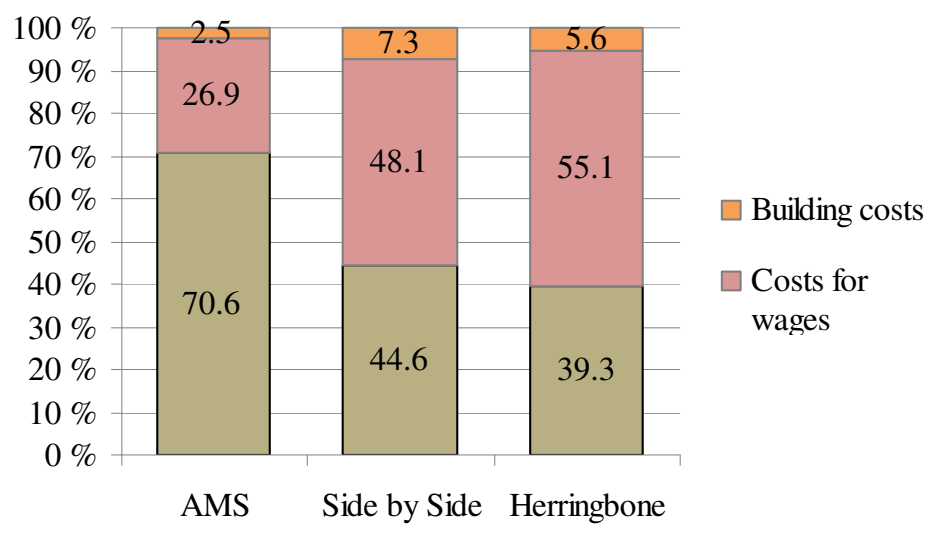

Fig. 2. Proportion of specific exploitation costs using different cow milking technologies (rate of wages for workers engaged in milking $5.00 \mathrm{EUR} \cdot \mathrm{h}^{-1}$, average milk yield $10000 \mathrm{~kg} \cdot \mathrm{year}^{-1}$ )

If, in turn, the stand type parlour equipment is used for milking cows, the machine costs of the milk cooler and cow mechanical mover, including also the costs of exploitation means, comprise 40$45 \%$ of the total exploitation costs. But the specific costs necessary for the wages of the milkers and cow movers increase approximately two times reaching 48-55\%. The same, building exploitation costs are 2-3 times higher as a considerably larger part of the premises is necessary for milking.

Dynamics of the changes of the total exploitation costs depending on the rate of the wages for the milkers and cow movers is given in Figure 3.

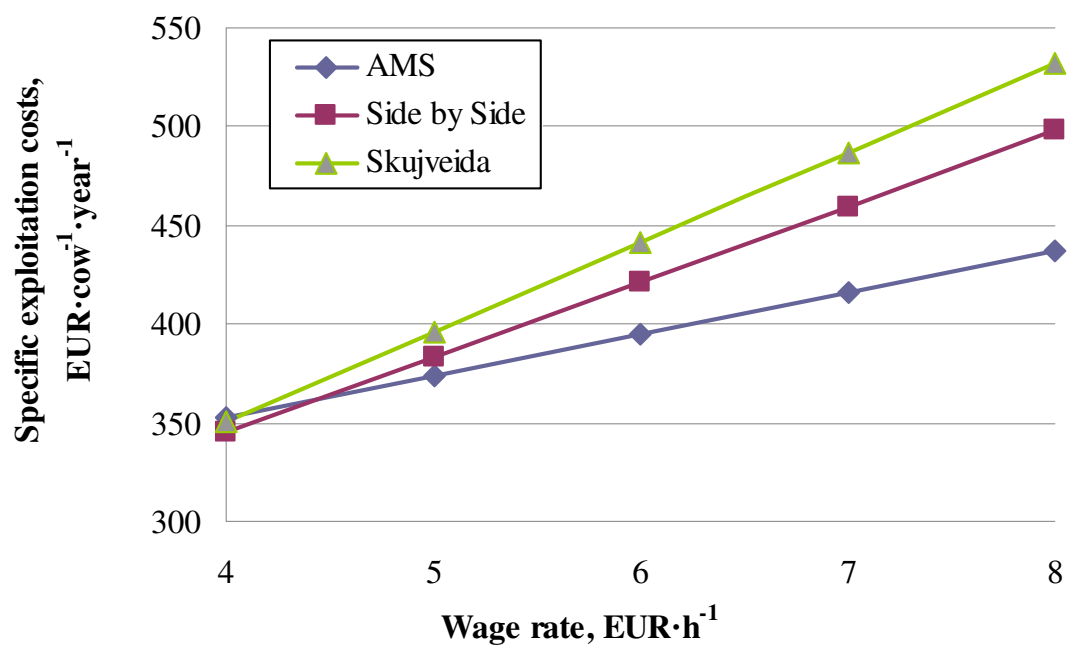

Fig. 3. Dynamics of changes of milking technological line specific exploitation costs depending on wage rate for people involved in milking (average milk yield $10000 \mathrm{~kg} \cdot \mathrm{year}^{-1}$ )

The figure shows that the milking technological line exploitation costs are changing directly proportionally to the wage rate for the workers. The higher the rate, the more increased the specific exploitation costs. If the wage rate for the workers does not exceed 4.0 EUR per hour, then the lowest specific exploitation costs are in the case of the stand type parlour milking equipment. But if the wages exceed 4.5-5.0 EUR per hour, the application of the AMS becomes cheaper.

According to the farm inspection results at present the wage rate for animal breeders is in the range from 3.5 to 6.0 EUR per one working hour. Calculating that in average every month they have to work for 160 working hours, it corresponds to 560 to 960 EUR per month. But it should be taken into account that these research results have been obtained in the farm, where one AMS serves the 
herd of 65 cows. If this load is less, the margin of profitability of introduction of the AMS will be at accordingly higher wages for the workers.

Similar research has been performed for the situation, when the average milk yield is $7000 \mathrm{~kg}$ of milk per year. In this case the amount of the specific exploitation costs reduces by some percents. It is related to the reduction of the milking time as well as the reduction of the consumption of electric energy necessary for cooling of milk and vacuum pump operation. Still, the obtained overview of the changes of exploitation costs is identical to the case given in Figure 3, when the average milk yield is $10000 \mathrm{~kg}$ of milk per year. It shows that the most important parameter, which determines the profitability of introduction of cow robotized milking, is the wages for the workers.

\section{Conclusions}

1. For introduction of AMS approximately two times higher capital investments are needed in comparison to side by side (parallel parlour) and herringbone parlour equipment, which are used for milking cows in milking yards, used to serve analogous size herds of cows. Nevertheless, usage of the AMS reduces the wages for the workers involved in the process of milking approximately two times.

2. The profitability of introduction of the AMS essentially depends on the wages for the animal breeders involved in the process of milking cows. If the amount of the wages exceeds 4.55.0 EUR per hour, the introduction of the AMs becomes more profitable compared to the usage of the side by side (parallel parlour) and herringbone parlour milking equipment for milking cows.

\section{References}

[1] Bonsels T. Automatische Melksysteme (AMS). BauBriefe Landwirtschaft 51. Deutscher Landwirtschaftsverlag GmbH, Hannover. 2012. 37.-46.S.

[2] Schön H. (eds). Automatische Melksysteme. KTBL, Darmstadt, 2000. 149 S.

[3] Fübbeker A., Kowalewsky H.H. Praxiserfahrung mit automatischen Melksystemen. KTBL, Darmstadt, 2005. $47 \mathrm{~S}$.

[4] Hinnerk Alberti J., Thomsen J. Wann rechnet sich ein Melkroboter? Top Agrar Ratgeber: Melkroboter Management. Landwirtschaftsverlag GmbH, 2012. 94.-97.S.

[5] Laurs A., Priekulis J., Purinš M. Studies of operating parameters in milking robots. $/ 8^{\text {th }}$ International Scientific Conference "Engineering for rural development". Jelgava, May 28-29, 2009. pp.38-42.

[6] Kic P. Criteria for optimization of milking parlour on dairy farm. $/ 14^{\text {th }}$ International Scientific Conference "Engineering for rural development". Jelgava, May 20-22, 2015. pp.106-111.

[7] Pezzuolo A., Cillis D., Marinello F., Sartori L. Estimating efficiency in automatic milking systems. $/ 16^{\text {th }}$ International Scientific Conference "Engineering for rural development". Jelgava, May 24-26, 2017. pp.736-741.

[8] Unal, H., Kuraloglu, H. Determination of operating parameters in milking robots with free cow traffic. $/ 14^{\text {th }}$ International Scientific Conference "Engineering for rural development". Jelgava, May 20-22, 2015. pp.100-105.

[9] Priekulis J., Latvietis J. Economic profitability of milk production. $/ 8^{\text {th }}$ International Scientific Conference "Engineering for rural development". Jelgava, May 28-29, 2009. pp.81-85.

[10] Priekulis J. Racionāla tehnolog̣ija un mehanizācija piena lopkopībā (Efficient Technology and Mechanization in Dairy Farming). Jelgava, LLU. 2000. - 148 lpp. (In Latvian). 